1 Atmospheric nitrogen deposition on petals enhances seed quality of the forest herb

2

3

4

5

6

7

8

9

10

11

12

13

14

15

16

17

18

19

20

21

22

23

24

25

26

27

28

29

30

31

32

33

34

35

36

37

38

39

40

\title{
Anemone nemorosa
}

Pieter De Frenne ${ }^{1,2 *}$, Haben Blondeel ${ }^{2}$, Jörg Brunet ${ }^{3}$, Maria Mercedes Caron ${ }^{2,4}$, Olivier Chabrerie ${ }^{5}$,

Mathias Cougnon ${ }^{1}$, Sara A.O. Cousins ${ }^{6}$, Guillaume Decocq ${ }^{5}$, Martin Diekmann7, Bente J. Graae,

Mick E. Hanley ${ }^{9}$, Thilo Heinken ${ }^{10}$, Martin Hermy ${ }^{11}$, Annette Kolb ${ }^{7}$, Jonathan Lenoir ${ }^{5}$, Jaan Liira ${ }^{12}$,

Anna Orczewska ${ }^{13}$, Anna Shevtsova ${ }^{14}$, Thomas Vanneste $^{1,2} \&$ Kris Verheyen ${ }^{2}$

1. Department of Plant Production, Ghent University, Proefhoevestraat 22, BE-9090 Melle, Belgium;

2. Forest \& Nature Lab, Ghent University, Geraardsbergsesteenweg 267, BE-9090 MelleGontrode, Belgium;

3. Southern Swedish Forest Research Centre, Swedish University of Agricultural Sciences, Box 49, SE-230 53 Alnarp, Sweden;

4. Laboratorio de Investigaciones Botánicas (LABIBO), Facultad de Ciencias Naturales, Universidad Nacional de Salta-CONICET, Av. Bolivia 5150, 4400 Salta, Argentina;

5. Unité de recherche "Ecologie et Dynamique des Systèmes Anthropisés" (EDYSAN, FRE3498 CNRS-UPJV), Université de Picardie Jules Verne, 1 rue des Louvels, FR80037 Amiens Cedex 1, France;

6. Biogeography and Geomatics, Department of Physical Geography, Stockholm University, SE-106 91 Stockholm, Sweden;

7. Vegetation Ecology and Conservation Biology, Institute of Ecology, FB2, University of Bremen, Leobener Str., DE-28359 Bremen, Germany;

8. Department of Biology, Norwegian University of Science and Technology, NO-7491 Trondheim, Norway;

9. School of Biological Sciences, University of Plymouth, Drake Circus, Plymouth, PL4 8AA, UK;

10. General Botany, University of Potsdam, Maulbeerallee 3, DE-14469 Potsdam, Germany;

11. Division Forest, Nature and Landscape, KULeuven, Celestijnenlaan 200E, BE-3001 Leuven, Belgium;

12. Institute of Ecology and Earth Sciences, University of Tartu, 40 Lai Street, EE-51005 Tartu, Estonia;

13. Department of Ecology, Faculty of Biology and Environmental Protection, University of Silesia, ul. Bankowa 9, PL-40-007 Katowice, Poland;

14. Department of Medical Biochemistry and Biophysics, Umeå University, SE-90187 Umeå, Sweden.

*Corresponding author: Pieter De Frenne, Tel +32 926490 30, Fax +32 926490 92; Email

Pieter.DeFrenne@,UGent.be

Short title: Seed quality and nitrogen deposition 
63

64 Keywords: latitudinal gradient; nutrient stoichiometry; seed quality; nitrogen deposition; seed

- Elevated atmospheric input of nitrogen $(\mathrm{N})$ is currently affecting plant biodiversity and ecosystem functioning. The growth and survival of numerous plant species is known to respond strongly to $\mathrm{N}$ fertilization. Yet, few studies have assessed the effects of $\mathrm{N}$ deposition on seed quality and reproductive performance, which is an important lifehistory stage of plants.

- Here we address this knowledge gap by assessing the effects of atmospheric $\mathrm{N}$ deposition on seed quality of the ancient forest herb Anemone nemorosa using two complementary approaches.

- By taking advantage of the wide spatiotemporal variation in $\mathrm{N}$ deposition rates in panEuropean temperate and boreal forests over two years, we detected positive effects of $\mathrm{N}$ deposition on the $\mathrm{N}$ concentration (percentage $\mathrm{N}$ per unit seed mass, increased from 2.8 to $4.1 \%$ ) and $\mathrm{N}$ content (total $\mathrm{N}$ mass per seed, more than doubled) of $A$. nemorosa seeds. In a complementary experiment, we applied ammonium nitrate to aboveground plant tissues and the soil surface to determine whether dissolved $\mathrm{N}$ sources in precipitation could be incorporated into seeds. Although the addition of $\mathrm{N}$ to leaves and the soil surface had no effect, a concentrated $\mathrm{N}$ solution applied to petals during anthesis resulted in increased seed mass, seed $\mathrm{N}$ concentration and $\mathrm{N}$ content.

- Our results demonstrate that $\mathrm{N}$ deposition on the petals enhances bioaccumulation of $\mathrm{N}$ in the seeds of Anemone nemorosa. Enhanced atmospheric inputs of $\mathrm{N}$ can thus not only affect growth and population dynamics via root or canopy uptake, but can also influence seed quality and reproduction via intake through the inflorescences. provisioning; sexual reproduction; wood anemone. 


\section{Introduction}

68 An ever-increasing number of anthropogenic stressors is acting on vegetation worldwide (Vellend $e t$

69

70 al. 2017). One of the key factors currently affecting plant biodiversity and ecosystem functioning are elevated atmospheric nitrogen (N) inputs (Bobbink et al. 2010; Simkin et al. 2016). Globally, atmospheric deposition of biologically reactive N more than tripled from 1860 to the early 1990s (Galloway et al. 2004), and remains high in many parts of Europe to date (Tørseth et al. 2012). The decades-long elevated $\mathrm{N}$ input is implicated with already significant losses of terrestrial plant diversity in many ecosystems across the globe (De Schrijver et al. 2011; Dirnböck et al. 2014; Basto et al. 2015; Simkin et al. 2016). One of the main reasons for plant species losses by $\mathrm{N}$ enrichment is through differential and species-specific $\mathrm{N}$ uptake and growth and, as a result, changed competitive interactions (Hautier et al. 2009).

Atmospheric deposition of ammonia $\left(\mathrm{NH}_{3}\right)$, ammonium $\left(\mathrm{NH}_{4}{ }^{+}\right)$, nitrogen oxides $\left(\mathrm{NO}_{\mathrm{x}}\right)$ and nitrate $\left(\mathrm{NO}_{3}^{-}\right)$can occur either as wet (with rainfall and snow) or dry deposition (input of particulate and gaseous compounds). The most widely studied pathway of how the elevated input of atmospheric $\mathrm{N}$ is acquired by plants is either through their root systems or through above-ground foliar surfaces (canopy exchange) (Adriaenssens et al. 2012). However, much less is known on how other plant organs can contribute to the uptake of atmospherically available N (Carlo \& Norris 2012). Recently, nevertheless, it was found that $\mathrm{N}$ ion uptake through permeable petal surfaces can be significant (up to $44 \%$ mass recovery rates); $\mathrm{N}$ that is subsequently allocated into ovaries and developing seeds (Carlo \& Norris 2012). This newly found pathway of petal $\mathrm{N}$ absorption and incorporation into the seeds can be especially important for plants with a high petal surface area over (total) seed mass ratio. Seed $\mathrm{N}$ concentrations (percentage $\mathrm{N}$ per unit seed mass) and contents (total $\mathrm{N}$ mass per seed) are key proxies for seed quality: they are positively associated with seedling fitness, establishment and survival, defence against herbivores (e.g. via synthesis of $\mathrm{N}$-containing secondary compounds such as alkaloids) and reproductive success (Hanley et al. 2004; Parrish \& Bazzaz 1985; 
importance though it has never been tested under realistic conditions of $\mathrm{N}$ deposition in the field.

95

96

97

98

99

100

101

102

103

104

105

106

107

108

109

110

111

112

113

114

115

116

117

118

Here we focus on the herbaceous forest understorey plant Anemone nemorosa, an important representative of the group of 'ancient woodland indicator species' in temperate Europe. The species is renowned for its typical slow colonization rates and associated failure to colonize recently established post-agricultural forests from, even nearby and adjacent, ancient forest patches (Brunet \& von Oheimb 1998; Verheyen et al. 2003; Baeten et al. 2010; De Frenne et al. 2011a; Brunet et al. 2012). Anemone nemorosa is also an excellent study species to study the effects of $\mathrm{N}$ deposition on its regeneration from seed because: (i) the species has relatively large petals (tepals) compared to its plant size and a relatively large flower surface area to capture both wet and dry deposition; (ii) it flowers during the spring (April-May), which is an active period for farmers spreading fertilizers on grasslands and croplands, with these activities typically resulting in high atmospheric concentrations of ammonia (Cools et al. 2016); (iii) being a vernal geophyte, it flowers before canopy tree leaves flush and is thus more exposed to wet $\mathrm{N}$ deposition due to the lower precipitation interception by the tree canopy at that time ( $c$. reduced 'shelter effect').

We here report the results of two complementary studies: first, we used a macroecological approach and sampled Anemone seeds over two years (2009 and 2013) across its European distributional range thereby taking advantage of the spatiotemporal continental-scale gradients in $\mathrm{N}$ deposition rates (typically decreasing from south to north; Fig. 1a). Second, we performed a controlled N addition experiment in which a solution of ammonium nitrate was applied to the petals and leaves of $A$. nemorosa and to the soil. We specifically addressed the hypotheses that (i) enhanced $\mathrm{N}$ deposition results in increased seed quality as quantified by means of the seed mass, $\mathrm{N}$ concentration and $\mathrm{N}$ content in the seeds, and (ii) only $\mathrm{N}$ addition specifically to the petals, rather than leaves or soil, increases seed quality. 
Anemone nemorosa L. (wood anemone; Ranunculaceae) is a perennial vernal forest rhizome geophyte common in deciduous Eurasian woodlands. Within Europe, the species has a latitudinal range from northern Spain to northern Sweden, and longitudinally from Ireland to the Ural (Hultén \& Fries 1986, Fig. 1b). Most closely associated with ancient woodlands (Verheyen et al. 2003; De Frenne et al. 2011a), A. nemorosa grows on not too nutrient-poor and acidic forest soils, relatively dry to wet. Shoots emerge between March and May and flowering starts a few weeks later. Flowers (one per ramet) have typically six white petals (tepals), are hermaphrodite, and mostly self-incompatible and insect pollinated, although selfing occurs (Müller et al. 2000). The achenes (mean of 10-30 per flower) contain a single seed and are gravity-, slug- and ant-dispersed between May and June (Delatte \& Chabrerie 2008; Türke et al. 2010). The indistinct elaiosome (appendix of the fruit, an adaptation to myrmecochory) of $A$. nemorosa is, in comparison to other myrmecochorous species, relatively rich in the fatty acids oleic acid and palmitic acid (Pfeiffer et al. 2009), both of which substances contain no N. Achenes (henceforth referred to as 'seeds') do not form a persistent seed bank (Eriksson 1995) or only a small short-term persistent seed bank (Plue et al. 2012). Vegetative spread through rhizomes is common (Philipp \& Petersen 2007), but sexual reproduction is considered to be most important for population spread (Brunet \& von Oheimb 1998; Müller et al. 2000). Anemone nemorosa typically has very slow colonization rates (Brunet \& von Oheimb 1998; Verheyen et al. 2003; De Frenne et al. 2011a; Brunet et al. 2012).

Study 1: Seed sampling along an N deposition gradient - macroecological approach

141 Seed sampling. In 2009 and 2013, seeds were sampled in 11 regions across Europe thereby taking 142 advantage of the spatiotemporal continental-scale variation in $\mathrm{N}$ deposition rates (Fig. 1a,b). All populations were large (>10,000 ramets) and situated in deciduous forest (mixed forests dominated

144 by deciduous species, in northern Sweden and Estonia) with 50-95 \% canopy cover unaffected by major recent disturbances (thinning, grazing, etc.). In 2009, two populations per region were 
sampled, each $>1 \mathrm{~km}$ apart (8 regions, 15 populations in total; only one population was sampled in northern Sweden due to the rarity in that region). In 2013, one population per region was sampled (11 populations from different regions). This resulted in a set of 26 populations $\times$ year combinations. At every collection site, we sampled and pooled the seeds of 30-50 randomly chosen ramets per population. Seed sampling was always performed at seed maturity, i.e., exactly at the moment when natural seed dispersal occurred (May-June).

$\mathbf{N}$ deposition and climate data. Since we are not working in sites with high topographic heterogeneity and in close vicinity of important point emission sources, the best available standardized $\mathrm{N}$ deposition data at the continental scale were obtained from the European Monitoring and Evaluation Programme database (EMEP) (http://www.emep.int). EMEP is the 'Co-operative Programme for Monitoring and Evaluation of the Long-range Transmission of Air Pollutants in Europe' and provides scientific information on the emission, transport and deposition of air pollutants in $50 \times 50 \mathrm{~km}$ grid cells covering Europe (Tørseth et al. 2012). Atmospheric deposition rates were calculated by summing the modelled rates of wet and dry oxidised and reduced N and expressed as $\mathrm{kg} \mathrm{ha}^{-1} \mathrm{year}^{-1}$. Data from 2009 and 2013 were used for the seeds sampled in the respective years. For simplicity, we assumed a dry deposition factor equal to 1 (that is, the factor by which dry deposition can be increased due to vegetation roughness) (Erisman \& Draaijers 2003). Data on N deposition ranged between 1.19 (Trondheim, central Norway) and $17.85 \mathrm{~kg} \mathrm{ha}^{-1}$ year $^{-1}$ (Ghent, Belgium) (Fig. 1a). Climate data were obtained from the CRU CL2.0 dataset using Fetchclimate 2 (Microsoft Research Cambridge, http://fetchclimate2.cloudapp.net). We extracted the mean annual and spring (February-May) temperature and precipitation for each population for 2009 and 2013, depending on the year of seed sampling. Only the mean annual temperature and precipitation were used in the analyses because these were strongly correlated with the spring temperature and precipitation (Pearson $\mathrm{r}=0.951, \mathrm{P}<0.001$ and $\mathrm{r}=0.911, \mathrm{P}<0.001$, respectively). The effects of soil characteristics (e.g., $\mathrm{pH}$, soil $\mathrm{P}, \mathrm{Ca}, \mathrm{K}, \mathrm{Mg}, \mathrm{N}, \mathrm{P}$ ) were not 
172 considered here since their effects on seed mass and $\mathrm{N}$ concentrations were shown to be negligible

173 in an earlier study ( $c f$. De Frenne et al. 2011c).

174

175

Study 2: $N$ addition experiment

176 Establishment of the experiment. The second study was a controlled addition experiment in

177 which an $\mathrm{N}$ ion solution was added with a paintbrush to the petals and leaves of $A$. nemorosa and to

178 the soil using a design adapted from Carlo \& Norris (2012). Rhizomes with emerging ramets were

179 collected in 2013 before flowering from an ancient deciduous forest dominated by Fraxinus excelsior

180 and Quercus robur in central Belgium (square in Fig. 1b) (latitude $50.975^{\circ} \mathrm{N}$, longitude $3.804^{\circ} \mathrm{E}$ ). The

181 experiment was also performed at this location. Following collection, rhizomes were transplanted

182 immediately into 1.5L-pots on 8 April 2013 using top $10 \mathrm{~cm}$-soil from the collection site. Pots were

183 installed in the forest but below transparent rain shelters (installed $c .1 \mathrm{~m}$ above the plants) such that

184 no natural precipitation could reach the pots, soil or plants. All pots were arranged randomly and

185 watered throughout the experiment with distilled water as needed, carefully avoiding the plant

186 tissue. We used five replicate pots for each of the nine treatment groups (control and a factorial

187 combination of $\mathrm{N}$ application type and concentration, see next section). All individuals were flowering when monitored on 12 April 2013.

189

190 Treatments. Plants were treated with aqueous ammonium nitrate solutions using two complementary approaches. First, $\mathrm{N}$ was applied with a paintbrush (type Marabu Forte 6) by repeatedly inserting the paintbrush in the $\mathrm{N}$ solution and then using a constant number of paintbrush strokes to deposit the solution. Specifically, leaves were treated with five paintbrush strokes randomly spread across the three leaves surrounding each flower. Petals were also treated with five strokes randomly spread across the six petals of each flower (carefully avoiding the carpels and anthers). To also apply the $\mathrm{N}$ solution to the soil, a circular filter paper of $c .20 \mathrm{~cm}^{2}$ was installed on the soil surface immediately surrounding the plant stem and also treated with five paintbrush strokes (after which the filter paper was rinsed with distilled water such that the $\mathrm{N}$ was 
washed into the soil and became potentially available to the plant; of. Carlo \& Norris 2012). Control plants were treated in exactly the same way, but using distilled water on the paintbrush. Secondly, the experiment included a treatment in which whole plants were sprayed with the same $\mathrm{N}$ solutions. This whole-plant approach mimicked a natural rainfall event by spraying all aboveground parts of the plants with a handheld sprinkler until water drops were visible on the entire plant. In all treatments, $\mathrm{N}$ solutions were applied spread over four occasions (on 15, 16, 23 and 26 April 2013).

$\mathbf{N}$ solutions and concentrations. We used ammonium and nitrate as $\mathrm{N}$ forms because these are the most abundant $\mathrm{N}$ ions in precipitation: the concentration of ammonia and nitrate in bulk openfield precipitation in central Belgium amounts to $0.85 \mathrm{mg} \mathrm{N} \mathrm{L}^{-1}$ and $0.50 \mathrm{mg} \mathrm{N} \mathrm{L}^{-1}$, respectively (Verstraeten et al. 2012), adding up to a total of $1.35 \mathrm{mg} \mathrm{N} \mathrm{L}^{-1}$. The long-term average precipitation during the flowering period of $A$. nemorosa (approximately one month) is $48 \mathrm{~mm}$ (1981-2010 April average for a weather station at $890 \mathrm{~m}$ distance from the experiment) resulting in a deposition of $64.8 \mathrm{mg} \mathrm{N} \mathrm{m}^{-2}$ (or $0.648 \mathrm{~kg} \mathrm{~N} \mathrm{ha}^{-1}$ ). This means that the $\mathrm{N}$ dose on the foliage of an average $A$. nemorosa ramet $\left(27 \mathrm{~cm}^{2}\right.$ leaf area ramet ${ }^{-1}$ is the mean of this species across Europe, De Frenne et al. 2011b) amounts to $0.17 \mathrm{mg} \mathrm{N}$ per ramet. The $\mathrm{N}$ dose on the petals of an average $A$. nemorosa flower ( $9 \mathrm{~cm}^{2}$ surface area flower-1 is the mean for this population) amounts to $0.06 \mathrm{mg} \mathrm{N}$ per flower. To determine the exact $\mathrm{N}$ dose, we then calculated the amount of water deposited on $A$. nemorosa petals and leaves by five paintbrush strokes. This amounted to $8.5 \mathrm{mg} \pm 1.0$ S.E. (determined from 8 replicate leaves) and $6.3 \mathrm{mg} \pm 1.0$ S.E. (determined from 8 replicate petals). To achieve a dose of $0.17 \mathrm{mg} \mathrm{N}$ per plant, spread over four applications each consisting of five paintbrush strokes, we thus needed to apply a solution with a concentration of $2.859 \mathrm{~g} \mathrm{NH}_{4} \mathrm{NO}_{3} \mathrm{~L}^{-1}\left(1.0 \mathrm{~g} \mathrm{~N} \mathrm{~L}^{-1}\right): 8.5 \mathrm{mg}$ $\mathrm{H}_{2} \mathrm{O} \times 4$ applications $\times 5$ strokes $\times 1.10^{-6} \mathrm{~g} \mathrm{~N} \mathrm{mg}^{-1} \mathrm{H}_{2} \mathrm{O}$. Our experiment also included a second scenario with a threefold concentration of $8.576 \mathrm{~g} \mathrm{NH}_{4} \mathrm{NO}_{3} \mathrm{~L}^{-1}\left(3.0 \mathrm{~g} \mathrm{~N} \mathrm{~L}^{-1}\right)$ that resulted in a dose of $0.51 \mathrm{mg} \mathrm{N}$ per plant $(0.38 \mathrm{mg} \mathrm{N}$ on the petals). In sum, the average $\mathrm{N}$ dose during the entire experiment using the low concentration applied to the leaves and petals was $0.17 \mathrm{mg} \mathrm{N}$ and 0.12 $\mathrm{mg} \mathrm{N}$, respectively, and $0.51 \mathrm{mg} \mathrm{N}$ and $0.38 \mathrm{mg} \mathrm{N}$ using the highly concentrated solution. This 
experimental design resulted in a total of 45 plants: 5 control plants (using the paintbrush with

227 distilled water), 30 plants in which either the flowers, leaves or soil were treated with the solution

228

229

230

231

232

233

234

235

236

237

238

239

240

241

242

243

244

245

246

247

248

249

250

251 To explore whether and to what extent the seed traits varied in response to variation in $\mathrm{N}$

252 with the low or high concentrations using the paintbrush, and finally 10 plants which were entirely sprayed with the sprinkler with either the low or high concentration. All seeds of each individual were sampled at seed maturity on 24 May 2013.

\section{Seed traits}

Seeds obtained from both experiments were air-dried to constant mass for $c .1$ week. We then determined mean seed mass by weighing all seeds (to the nearest $0.1 \mathrm{mg}$ ) per seed sample and dividing the obtained mass by the number of seeds. A subsample of seeds was then oven-dried to constant mass $\left(50{ }^{\circ} \mathrm{C}\right.$ for $72 \mathrm{~h}$ ) and analysed for $\mathrm{C}$ and $\mathrm{N}$ using a CNS element analyser (expressed in $\%$ ) and $\mathrm{C}: \mathrm{N}$ ratios calculated from these results. The seed $\mathrm{N}$ content per seed $\left(\mathrm{mg} \mathrm{N}^{-1} \mathrm{sed}^{-1}\right)$ was calculated by multiplying the $\mathrm{N}$ concentration (\%) with the seed mass (mg). The response variables for both experiments were the seed mass, seed $\mathrm{C}$ and $\mathrm{N}$ concentrations and seed C:N ratio and $\mathrm{N}$ content since these are key variables reflecting seed quality and provisioning, and potential seedling survival and reproductive success (Parrish \& Bazzaz 1985; De Frenne et al. 2011c). Illustratively, seed mass is strongly correlated to germination percentages in this species (De Frenne et al. 2011c: $r$ $=0.656, P<0.05)$. We did not consider other seed nutrients such as $\mathrm{K}, \mathrm{Ca}$ or $\mathrm{P}$ for this study because these are unlikely to strongly respond to petal $\mathrm{N}$ addition and did not show major variation in this species with latitude (De Frenne et al. 2011c). Furthermore, no alkaloids were detected in Anemone seeds (De Frenne et al. 2011c). This is noteworthy since plants can invest a substantial part of their $\mathrm{N}$ in secondary compounds, especially in the Ranunculaceae family. Thus, most probably all $\mathrm{N}$ in the seeds is present as free amino acids and/or proteins.

\section{Data analyses} deposition rates and climate over time and space in Study 1, we applied linear mixed-effect models 
253 using the Imer-function from the lme4-package in R (R Core Team 2017). Random effect terms

254 'region' and 'population' nested within 'region' were added to the multilevel models to account for

255 the hierarchical nature of the data and the spatiotemporal autocorrelation within populations and

256 regions. We also added a non-nested random effect 'year' to account for the repeated sampling in

2572009 and 2013 in the same populations (Zuur et al. 2009). To avoid multicollinearity issues of the

258 explanatory variables temperature and $\mathrm{N}$ deposition within the same model, the effects of the

259 predictors were always tested using separate models (one-by-one). Correlations among predictors

260 were as follows: temperature vs. $\mathrm{N}$ deposition: $\mathrm{r}=0.870, \mathrm{P}<0.001$; temperature vs. precipitation: $\mathrm{r}$

$261=0.202, \mathrm{P}=0.284 ; \mathrm{N}$ deposition vs. precipitation: $\mathrm{r}=0.0674, \mathrm{P}=0.723$.

262

263 The seed quality data from Study 2 were first expressed as response ratios with the natural

264 logarithm of the ratio of the seed traits $\left(x_{\mathrm{i}}\right)$ divided by the mean seed traits of the control plants

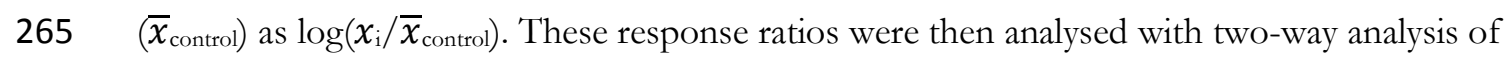

266 variance (ANOVA) with the treatment (soil, leaves, flowers or entire plant treated with N) and

267 concentration (low vs. high) as factors using the aov-function in R (R Core Team 2017). 


\section{Results}

269 In Study 1, seed traits exhibited strong spatial variation matching closely the estimated $\mathrm{N}$ deposition rates across Europe (Fig. 2; Table 1). Seed N concentrations and N contents were strongly positively correlated with $\mathrm{N}$ deposition while C:N ratios decreased with $\mathrm{N}$ deposition. For instance,

$272 \mathrm{~N}$ concentrations increased, on average, from c. $2.8 \%$ seed $\mathrm{N}$ at $\mathrm{N}$ deposition levels of $1 \mathrm{~kg} \mathrm{~N} \mathrm{ha}^{-1}$

$273 \mathrm{yr}^{-1}$ to $c .4 .1 \%$ at $\mathrm{N}$ deposition levels of $18 \mathrm{~kg} \mathrm{~N} \mathrm{ha}^{-1} \mathrm{yr}^{-1}$ (Fig. 2b,d; Table 1). By contrast, seed mass

274 and seed C concentrations did not differ significantly in seeds sampled from regions with high vs.

275 low levels of $\mathrm{N}$ deposition. Second, temperature was also related to the seed traits along the

276 latitudinal gradient with significant positive effects on $\mathrm{N}$ concentration and content and negative

277 effects on seed C:N ratios. Yet, the AIC values of the temperature models were consistently higher

278 for all seed traits than of the models with $\mathrm{N}$ deposition as predictor, which demonstrates the higher

279 relative importance of $\mathrm{N}$ deposition for seed traits of $A$. nemorosa along the latitudinal transect

280 (Table 1). Precipitation did not demonstrably influence any of the investigated seed traits.

281 Nevertheless, to experimentally disentangle the effects of $\mathrm{N}$ deposition from potentially

282 confounding effects of other environmental changes along the latitudinal gradient, we designed the experiment in Study 2.

284 Seed traits also responded significantly to the experimental $\mathrm{N}$ treatments in the controlled Study 2,

285 but mostly to the highly concentrated solution (Fig. 3; Table 2). There were significant differences

286 between the mass of seeds, seed $\mathrm{N}$ concentration, C:N ratios and $\mathrm{N}$ content in the contrasting

287 treatments, with, for instance, seeds containing more $\mathrm{N}$ if petals received additional $\mathrm{N}$ (Fig. 3). Seed $\mathrm{N}$ concentrations varied significantly with treatments, increasing from $c .2 .8 \%$ to $3.2 \%$ when petals were treated with $\mathrm{N}$ compared to the control treatment (Fig. 3b). Nonetheless, the concentration of the solution did not significantly affect this result. Finally, the seed $\mathrm{N}$ content responded both to the $\mathrm{N}$ addition treatment as well as the applied concentration (Fig. 3d). Seed $\mathrm{C}$ concentrations were not significantly affected (Table 2). Addition of $\mathrm{N}$ to the leaves and soil did not affect seed $\mathrm{N}$ concentrations, but spraying the entire plant resulted in similar responses of seed traits as addition of $\mathrm{N}$ to the petals alone (Fig. 3). 
296 We detected consistent effects of $\mathrm{N}$ deposition on seed traits of Anemone nemorosa. Seed N

297 concentrations and total seed $\mathrm{N}$ content increased with large-scale $\mathrm{N}$ deposition patterns in the observatory across Europe (Study 1) and with experimental N addition (Study 2). We previously established a strong north-south gradient in seed $\mathrm{N}$ concentrations in this forest herb, but the causes behind this mechanism remained unknown (De Frenne et al. 2011c). With the observational and experimental results reported here, we identify the likely driver for observed latitudinal clines in seed $\mathrm{N}$ concentrations as we demonstrate that $\mathrm{N}$ deposition on petals during anthesis enhances bioaccumulation of $\mathrm{N}$ in seeds. Deposition of $\mathrm{N}$ on the leaves and soil alone did not meaningfully change seed $\mathrm{N}$ concentrations, but when $\mathrm{N}$ was applied to the whole plant, patterns were similar as in the petal treatments. Our results thus corroborate Carlo \& Norris (2012) who showed that petals can act as permeable membranes through which $\mathrm{N}$ is readily incorporated in the reproductive structures, most likely via $\mathrm{N}$ transport to the ovaries and seeds via the phloem (Zhang et al. 2010). Additionally, water droplets might flow over the petal surface to reach the ovaries, or dry deposits may be wetted by rainfall and as such transported directly to the ovaries. The lack of significant effects of precipitation on seed traits might indicate non-negligible effects of dry deposition. This is confirmed by the $\mathrm{N}$ concentrations obtained in the experiment where we only manipulated wet deposition. $\mathrm{N}$ concentrations there reached $c .3 .2 \%$, while maximal concentrations of more than 4 $\%$ were obtained in the field in Study 1.

Changes in seed size and quality as a result of enhanced atmospheric $\mathrm{N}$ deposition are likely to have important ecological implications. Enhanced $\mathrm{N}$ accumulation in seeds resulting from $\mathrm{N}$ deposition may increase resources available for embryo development, seedling nutrition and establishment. Most probably, this $\mathrm{N}$ is stored as free amino acids and proteins (no secondary $\mathrm{N}$ compounds such as alkaloids for defence against herbivores are present in $A$. nemorosa seeds, see Materials and

320 Methods). Bioassays on seeds of a wide range of species show that the usable internal $\mathrm{N}$ reserves 321 depleted the quickest of all nutrients after germination (Fenner \& Thompson 2005). This means 
322 that even small differences in seed $\mathrm{N}$ provisioning can improve seedling survival and fitness in

323 adverse abiotic and biotic environments such as shady or nutrient-poor habitats, during drought

324 episodes and heat waves, and under intense competition for resources (Parrish \& Bazzaz 1985;

325 Moles \& Westoby 2004; Naegle et al. 2005; De Frenne et al. 2011c; but see Hanley et al. 2007). These

326 processes can in turn, influence plant population dynamics and community composition.

327 Accordingly, community changes in response to fertilization might not only be due to changes in

328 above- and below-ground competitive interactions for light or nutrients (Hautier et al. 2009), but

329 may also result from altered seed provisioning and differential recruitment. Nitrogen uptake

330 through permeable surfaces of petals can also be advantageous to flowering plants in the absence of

331 elevated atmospheric $\mathrm{N}$ deposition. For example, arthropod pollinators such as honeybees deposit

332 significant amounts of ammonium and nitrate via their faeces (Mishra et al. 2013). Deposition of N

333 via faeces on petals can thus efficiently be incorporated into the seeds. Finally, diaspores of $A$.

334 nemorosa and numerous other forest herbs are ingested and dispersed by ants and slugs (Delatte \&

335 Chabrerie 2008; Türke et al. 2010) and changes in their chemical composition may affect the

336 probability of diaspore removal and ingestion (Reifenrath et al. 2012), and consequently species

337 colonization and trophic interactions.

338

339 Scaling up to the population and species level, we expect a positive impact of elevated $\mathrm{N}$ deposition

340 on A. nemerosa recruitment and population dynamics, especially in the longer run. Nevertheless,

341 previous field studies found mixed results, which varied strongly according to the amount of annual

$342 \mathrm{~N}$ addition and the sampling period. For instance, in an experiment with addition of not less than

$343180 \mathrm{~kg} \mathrm{~N} \mathrm{ha}^{-1} \mathrm{yr}^{-1}$ in a forest in southern Sweden, Falkengren-Grerup (1993) detected a significantly

344 reduced shoot length, flowering frequency, cover and biomass of $A$. nemorosa relative to the control

345 after six years. Clearly, the applied $\mathrm{N}$ level was much higher than the levels of atmospheric $\mathrm{N}$

346 deposition in this study. In a field experiment in Belgium with application of $100 \mathrm{~kg} \mathrm{~N} \mathrm{ha}^{-1} \mathrm{yr}^{-1}$, the

347 percentage ground cover of $A$. nemorosa declined significantly by $32 \%$ over 6 years of $\mathrm{N}$ application

348 (unpublished data, experiment described in De Frenne et al. 2015). In the last five decades, the 
349 frequency of occurrence of $A$. nemorosa in resurveyed semi-permanent vegetation plots within

350 ancient woodlands across Europe has also not changed dramatically (on average this changed from 35146.3 to $45.2 \%$; De Frenne et al. 2013).Undoubtedly, other global environmental changes such as 352 climate change, land-use change and management change interact with $\mathrm{N}$ deposition to affect 353 population dynamics and the species' distribution, and thus play an important role in determining 354 the ultimate response of populations at the continental scale (Baeten et al. 2010). The mixed results 355 at the population level between previous N addition field experiments (Falkengren-Grerup 1993, 356 De Frenne et al. 2015) and this study are likely due to $\mathrm{N}$ addition that was not added exclusively on A. nemorosa petals in the other experiments and thus such changes likely reflect negative effects of

$358 \mathrm{~N}$ addition on adult cover and biomass, and not on recruitment and reproductive success via petal uptake.

Since $\mathrm{N}$ deposition rates across Europe correlate with other environmental changes from north to south (most notably, temperature), it is difficult to distinguish correlation from causation in Study 1. Nonetheless, in the controlled pot experiment of Study 2, only $\mathrm{N}$ addition was manipulated; all other biotic and abiotic environmental variables (temperature, soil moisture, soil nutrients, canopy cover, etc.) were kept as constant as possible. Taking our two sub-studies together, our results support a dominant role of $\mathrm{N}$ deposition on petals in explaining the observed patterns in seed traits of this species. More generally, we hypothesise that a wide array of plant species (specifically those with relatively large petals and small seeds) in regions with high levels of atmospheric $\mathrm{N}$ inputs currently display higher seed mass, $\mathrm{N}$ concentrations and contents than before the historical onset of enhanced air pollution and $\mathrm{N}$ emissions. Whether enhanced atmospheric inputs of $\mathrm{N}$ via direct

371 intake by petals can influence demography, and population and community dynamics clearly warrants further research, for example, by subjecting seedlings resulting from seeds with contrasting $\mathrm{N}$ concentrations to stress and/or herbivory experiments and by performing seed dispersal and cafeteria experiments with seeds of contrasting $\mathrm{N}$ concentrations. 


\section{Acknowledgements}

376 We thank the Research Foundation - Flanders (FWO) for funding the scientific research network

377 FLEUR (www.fleur.ugent.be). PDF was supported by the FWO and KV held an ERC

378 Consolidator Grant 614839 - PASTFORWARD. Special thanks are due to Luc Willems and Greet

379 De bruyn for the chemical analyses and laboratory assistance. 
Adriaenssens S., Hansen K., Staelens J., Wuyts K., De Schrijver A., Baeten L., Boeckx P., Samson R., Verheyen K. (2012) Throughfall deposition and canopy exchange processes along a vertical gradient within the canopy of beech (Fagus sylvatica L.) and Norway spruce (Picea abies (L.) Karst). Science of the Total Environment, 420, 168-182.

385 Baeten L., De Frenne P., Verheyen K., Graae B.J., Hermy M. (2010) Forest herbs in the face of global 386 change: a single-species-multiple-threats approach for Anemone nemorosa. Plant Ecology and Evolution, 143, 19-30.

387 Basto S., Thompson K., Phoenix G., Sloan V., Leake J., Rees M. (2015) Long-term nitrogen deposition 388 depletes grassland seed banks. Nature Communications, 6, 6185.

389 Bobbink R., Hicks K., Galloway J., Spranger T., Alkemade R., Ashmore M., Bustamante M., Cinderby S., 390 Davidson E., Dentener F., Emmett B., Erisman J.W., Fenn M., Gilliam F., Nordin A., Pardo L., De Vries W. 391 (2010) Global assessment of nitrogen deposition effects on terrestrial plant diversity: a synthesis. Ecological 392 Applications, 20, 30-59.

Brunet J., De Frenne P., Holmström E., Mayr M.L. (2012) Life-history traits explain rapid colonization of young post-agricultural forests by understory herbs. Forest Ecology and Management, 278, 55-62.

Brunet J., Oheimb G. Von, von Oheimb G. (1998) Colonization of secondary woodlands by Anemone nemorosa. Nordic Journal of Botany, 18, 369-377.

Carlo T.A., Norris A.E.W. (2012) Direct nitrogen intake by petals. Oikos, 121, 1953-1958.

401 De Frenne P., Baeten L., Graae B.J., Wulf M., Jacquemyn H., Orczewska A., Kolb A., Jansen I., Hermy M.,

402 Diekmann M., Schrijver A. De, Sanctis M. De, Decocq G., Cousins S.A.O., Verheyen K. (2011a)

403 Interregional variation in the floristic recovery of post-agricultural forests. Journal of Ecology, 99, 600-609.

404 De Frenne P., Graae B.J., Kolb A., Shevtsova A., Baeten L., Brunet J., Chabrerie O., Cousins S.A.O., Decocq 405 G., Dhondt R., Diekmann M., Gruwez R., Heinken T., Hermy M., Öster M., Saguez R., Stanton S., Tack W., 406 Vanhellemont M., Verheyen K. (2011b) An intraspecific application of the leaf-height-seed ecology strategy 407 scheme to forest herbs along a latitudinal gradient. Ecography, 34, 132-140.

408 De Frenne P., Kolb A., Graae B.J., Decocq G., Baltora S., De Schrijver A., Brunet J., Chabrerie O., Cousins 409 S.A.O., Dhondt R., Diekmann M., Gruwez R., Heinken T., Hermy M., Liira J., Saguez R., Shevtsova A., 410 Baskin C.C., Verheyen K. (2011c) A latitudinal gradient in seed nutrients of the forest herb Anemone nemorosa. 411 Plant Biology, 13, 493-501.

412 De Frenne P., Rodríguez-Sánchez F., Coomes D.A., Baeten L., Verstraeten G., Vellend M., Bernhardt413 Römermann M., Brown C.D., Brunet J., Cornelis J. (2013) Microclimate moderates plant responses to 414 macroclimate warming. Proceedings of the National Academy of Sciences, 110, 18561-18565.

415 De Frenne P., Rodríguez-Sánchez F., De Schrijver A., Coomes D. a., Hermy M., Vangansbeke P., Verheyen 416 K. (2015) Light accelerates plant responses to warming. Nature Plants, 1, 15110.

417 Delatte É., Chabrerie O. (2008) Performances des plantes herbacées forestières dans la dispersion de leurs 418 graines par la fourmi Myrmica ruginodis. Comptes Rendus Biologies, 331, 309-320. 
419 De Schrijver A., De Frenne P., Ampoorter E., van Nevel L., Demey A., Wuyts K., Verheyen K. (2011)

420 Cumulative nitrogen input drives species loss in terrestrial ecosystems. Global Ecology and Biogeography, 20, 803-

421816

422 Dirnböck T., Grandin U., Bernhardt-Römermann M., Beudert B., Canullo R., Forsius M., Grabner M.,

423 Holmberg M., Kleemola S., Lundin L. (2014) Forest floor vegetation response to nitrogen deposition in

424 Europe. Global Change Biology, 20, 429-440.

425 Eriksson O. (1995) Seedling recruitment in deciduous forest herbs: the effects of litter, soil chemistry and

426 seed bank. Flora, 190, 65-70.

427 Erisman J.W., Draaijers G. (2003) Deposition to forests in Europe: Most important factors influencing dry

428 deposition and models used for generalisation. Environmental Pollution, 124, 379-388.

429 Falkengren-Grerup U. (1993) Effects on beech forest species of experimentally enhanced nitrogen

430 deposition. Flora, 188, 85-91.

431 Fenner M., Thompson K. (2005) The Ecology of Seeds. Cambridge University Press, Cambridge, UK.

432 Galloway J.N., Dentener F.J., Capone D.G., Boyer E.W., Howarth R.W., Seitzinger S.P., Asner G.P.,

433 Cleveland C.C., Green P.A., Holland E.A., Karl D.M., Michaels A.F., Porter J.H., Townsend A.R.,

434 Vörösmarty C.J. (2004) Nitrogen cycles: Past, present, and future. Biogeochemistry, 70, 153-226.

435 Hanley M.E., Fenner M., Whibley H., Darvill B. (2004) Early plant growth: Identifying the end point of the 436 seedling phase. New Phytologist, 163:61-66.

437 Hanley M.E., Cordier P.K., May O.C., Kelly C.K. (2007) Seed size and seedling growth: differential response

438 of Australian and British Fabaceae to nutrient limitation. New Phytologist, 174, 381-388.

439 Hautier Y., Niklaus P.A., Hector A. (2009) Competition for Light Causes Plant Biodiversity Loss After

440 Eutrophication. Science, 324:636-638.

441 Hultén E., Fries M. (1986) Atlas of North European V ascular Plants: North of the Tropic of Cancer. Koeltz Scientific,

442 Königstein, Germany.

443 Mishra A., Afik O., Cabrera M.L., Delaplane K.S., Mowrer J.E. (2013) Inorganic Nitrogen Derived from

444 Foraging Honey Bees Could Have Adaptive Benefits for the Plants They Visit. PLoS ONE, 8, 1-6.

445 Moles A.T., Westoby M. (2004) Seedling Survival and Seed Size: A Synthesis of the Literature. Journal of

446 Ecology, 92, 372-383.

447 Müller N., Schneller J.J., Holderegger R. (2000) Variation in breeding system among populations of the

448 common woodland herb Anemone nemorosa (Ranunculaceae). Plant Systematics and Evolution, 221, 69-76.

449 Naegle E.R., Burton J.W., Carter T.E., Rufty T.W. (2005) Influence of seed nitrogen content on seedling

450 growth and recovery from nitrogen stress. Plant and Soil, 271, 329-340.

451 Parrish A.J.A.D., Bazzaz F.A. (1985) Nutrient Content of Abutilon theophrasti Seeds and the Competitive

452 Ability of the Resulting Plants. Oecologia, 65, 247-251.

453 Pfeifer M., Huttenlocher H., Ayasse, M. (2010) Myrmecochorous plants use chemical mimicry to cheat seed-

454 dispersing ants. Functional Ecology, 24, 545-555. 
455 Philipp M., Petersen P.M. (2007) Long-term study of dry matter allocation and rhizome growth in Anemone

456 nemorosa. Plant Species Biology, 22, 23-31.

457 Plue J., Thompson K., Verheyen K., Hermy M. (2012) Seed banking in ancient forest species: why total

458 sampled area really matters. Seed Science Research, 22, 123-133.

459 R Core Team (2017) R: A language and environment for statistical computing. R Foundation for Statistical

460 Computing, Vienna, Austria.

461 Reifenrath K., Becker C., Poethke H.J. (2012) Diaspore Trait Preferences of Dispersing Ants. Journal of

462 Chemical Ecology, 38, 1093-1104.

463 Simkin S.M., Allen E.B., Bowman W.D., Clark C.M., Belnap J., Brooks M.L., Cade B.S., Collins S.L., Geiser

464 L.H., Gilliam F.S., Jovan S.E., Pardo L.H., Schulz B.K., Stevens C.J., Suding K.N., Throop H.L., Waller D.M.

465 (2016) Conditional vulnerability of plant diversity to atmospheric nitrogen deposition across the USA.

466 Proceedings of the National Academy of Sciences of the United States of America, 113, 4086-4091.

467 Tørseth K., Aas W., Breivik K., Fjeraa A.M., Fiebig M., Hjellbrekke A.G., Lund Myhre C., Solberg S., Yttri 468 K.E. (2012) Introduction to the European Monitoring and Evaluation Programme (EMEP) and observed 469 atmospheric composition change during 1972-2009. Atmospheric Chemistry and Physics, 12, 5447-5481.

470 Türke M., Heinze E., Andreas K., Svendsen S.M., Gossner M.M., Weisser W.W. (2010) Seed consumption

471 and dispersal of ant-dispersed plants by slugs. Oecologia, 163, 681-693.

472 Vellend M., Baeten L., Becker-scarpitta A., Mccune J.L., Messier J., Myers-smith I.H., Sax D.F. (2017) Plant

473 Biodiversity Change Across Scales During the Anthropocene. Annual Review of Plant Biology, 68, 563-586.

474 Verheyen K., Honnay O., Motzkin G., Hermy M., Foster D.R. (2003) Response of forest plant species to

475 land-use change: A life-history trait-based approach. Journal of Ecology, 91, 563-577.

476 Verstraeten A., Neirynck J., Genouw G., Cools N., Roskams P., Hens M. (2012) Impact of declining

477 atmospheric deposition on forest soil solution chemistry in Flanders, Belgium. Atmospheric Environment, 62 ,

478 50-63.

479 Zhang L., Tan Q., Lee R., Trethewy A., Lee Y.-H., Tegeder M. (2010) Altered Xylem-Phloem Transfer of 480 Amino Acids Affects Metabolism and Leads to Increased Seed Yield and Oil Content in Arabidopsis. The

481 Plant Cell, 22, 3603-3620.

482 Zuur A.F., Ieno E.N., Walker N., Saveliev A.A., Smith G.M. (2009) Mixed Effects Models and Extensions in

483 Ecology with R. Springer, New York, USA. 
485 Table 1. Effects of $\mathrm{N}$ deposition rates, temperature and precipitation on seed traits of Anemone

486

487

488 nemorosa across Europe. Results from Study 1 (macroecological approach) using linear mixed-effect models with $\mathrm{N}$ deposition rates and climatic variables as predictor variables (see Materials and Methods).

\begin{tabular}{|c|c|c|c|c|c|}
\hline Predictor & Response variable & $\begin{array}{l}\text { Parameter } \\
\text { estimate }\end{array}$ & $\mathrm{Chi}^{2}$-value & P-value ${ }^{1}$ & AIC \\
\hline \multirow[t]{5}{*}{$\mathbf{N}$ deposition } & Seed mass & $4.55 \times 10^{-2}$ & 0.84 & 0.361 (ns) & 86.4 \\
\hline & Seed C concentration & $-9.8 \times 10^{-2}$ & 2.49 & 0.114 (ns) & 134.7 \\
\hline & Seed $\mathrm{N}$ concentration & $7.58 \times 10^{-2}$ & 13.85 & $<0.001 * * *$ & 55.4 \\
\hline & Seed $\mathrm{C}: \mathrm{N}$ ratio & $-4.01 \times 10^{-1}$ & 14.13 & $<0.001 * * *$ & 153.7 \\
\hline & Seed $\mathrm{N}$ content & $3.9 \times 10^{-3}$ & 6.63 & $0.010 *$ & -109.6 \\
\hline \multirow[t]{5}{*}{ Temperature } & Seed mass & $8.41 \times 10^{-2}$ & 0.314 & 0.575 (ns) & 86.9 \\
\hline & Seed C concentration & $-1.31 \times 10^{-1}$ & 0.75 & 0.386 (ns) & 136.5 \\
\hline & Seed N concentration & $1.63 \times 10^{-1}$ & 10.80 & $0.0010 * *$ & 58.4 \\
\hline & Seed C: $\mathrm{N}$ ratio & $-8.47 \times 10^{-1}$ & 10.32 & $0.0013 * *$ & 157.5 \\
\hline & Seed $\mathrm{N}$ content & $7.05 \times 10^{-3}$ & 3.82 & $0.051\left(^{*}\right)$ & -106.8 \\
\hline \multirow[t]{5}{*}{ Precipitation } & Seed mass & $5.41 \times 10^{-5}$ & 0.65 & 0.999 (ns) & 87.9 \\
\hline & Seed $\mathrm{C}$ concentration & $-9.98 \times 10^{-4}$ & 0.15 & 0.698 (ns) & 137.1 \\
\hline & Seed $\mathrm{N}$ concentration & $2.29 \times 10^{-4}$ & 0.27 & 0.606 (ns) & 68.9 \\
\hline & Seed C: $\mathrm{N}$ ratio & $-1.40 \times 10^{-3}$ & 0.30 & 0.587 (ns) & 167.5 \\
\hline & Seed N content & $1.06 \times 10^{-5}$ & 0.01 & 0.999 (ns) & -103.0 \\
\hline
\end{tabular}


490 Table 2. Effects of the experimental $\mathrm{N}$ addition treatments (leaves, flowers, soil or entire plant

491 treated with $\mathrm{N}$ as levels) and concentrations (low vs. high as levels), and their interaction, on seed

492 traits of Anemone nemorosa. Results from the experimental Study 2 using log-response ratios and two-

493 way ANOVAs (see Materials and Methods).

\begin{tabular}{|l|l|l|l|}
\hline Response variable & Treatment & Concentration & Treatment: \\
Concentration
\end{tabular}

494

Significances are indicated: (ns): $\mathrm{P}>0.10 ;(*): \mathrm{P}<0.10 ; *$ : $<0.05$. 
496 Fig. 1. Illustration of the $\mathrm{N}$ deposition gradient used in this study: (a) Relationship between latitude

$497\left({ }^{\circ} \mathrm{N}\right)$ and $\mathrm{N}$ deposition rates $\left(\mathrm{kg} \mathrm{N} \mathrm{ha}^{-1} \mathrm{yr}^{-1}\right)$ of the study sites. The fitted grey line denotes a mixed-

498 effect model with random-effect term 'region'. (b) Distribution range of Anemone nemorosa after

499 Hultén \& Fries (1986) (grey shaded area) and sampling sites along the N deposition gradient (circles

500 and square) and location of the experiment (square).

501

502 Fig. 2. Relationships between $\mathrm{N}$ deposition rates $\left(\mathrm{kg} \mathrm{N} \mathrm{ha}^{-1} \mathrm{yr}^{-1}\right)$ and the measured seed traits of

503 Anemone nemorosa seeds sampled along an $\mathrm{N}$ deposition gradient in Europe (Study 1:

504 macroecological approach). Fitted regression lines are the linear mixed-effect models shown in

505 Table 1, dashed lines are not significant at $\mathrm{P}>0.1$, solid lines are significant at $\mathrm{P}<0.05$.

506

507 Fig. 3. Effects of $\mathrm{N}$ addition using a solution with low (open circles) and high (grey circles) $\mathrm{N}$ ion

508 concentration to the soil, leaves and petals of the flowers or the entire plant on seed traits of

509 Anemone nemorosa (Study 2). The control treatment is shown with a larger black circle. Error bars

510 denote standard errors. 